\title{
長大栈橋を利用した容量型波高計群による 波浪観測について
}

\author{
土屋義人*·山口正隆**.芹沢重厚***
}

\section{1. 緒言}

最近沿岸海洋の高度利用に伴って, 各種の波浪観測が 実施されてきたが，浅海における波浪の変形などの観測 には，海岸から沖方向に設置された棧橋がきわめて有効 であることは，すでに岩坦 ${ }^{1)}$ てっっ強調されていると ころである。防災研究所附属大潟波浪観測所では, 帝国 石油 K.K. の第 1 人工島長大棧橋を利用して，1965 年 より浅海における波浪観測を階段抵抗式波高計によって 実施してかなりの成果をあげてきたが，棧橋の鋼管杭に 取付けた波高桿への波のうちあげなどが問題となって， 詳細な波の变形特性の究明には少なからず支障をきたし てきた。このために，今回これらの問題点を解消して， 浅海における波の変形, 特に方向スペクトル, 屈折によ る波の分散，砕波後の波の変形，海底摩擦および平均海 面の变動などを究明するために，若干の集中観測を実施 したので，ここではその方法と得られた興味ある二，三 の結果について報告する。

\section{2. 容量型波高計群と観測方法}

\section{（1）容量型波高計}

被覆電線と海水との間の電気容量が水面の变動によっ て変化することを利用したこの種の波高計は最近ではか なり普及してきたが2)，乙れは次のような長所に依存す るものと思われる。電気容量の変化を搬送電圧の変化と し，これを検波後増幅して記録させるので，出力に対す る直線性がきわめてよく, 記録後の較正を必要としな い。また，抵抗線式波高計のように，水質による影響を ほとんどうけず，被覆電線の太さの影響は実際上皆無で あるので，たとえば超音波式波高計のような波形のひず みも生じない。そのう光, 増幅器の一部の回路の交換に よって，数十七ンチメートルから十数メートル程度まで 約 $0.1 \%$ の精度で測定することができ，また搬送波に高 周波を用いるために，100Hz $\pm 1 \mathrm{db}$ 程度の高周波領域宋 で測定可能である。センサーとしては被覆が一様であれ ばそれぞれの用途によって適宣選択することができる。 一方, これらの長所に対して, 唯一の短所は長時間の使
用による水あかの付着の影響と漂流物に対するセンサー の保護の問題である。

この観測では, 以上の諸点を考虑して次の仕様による 容量型波高計を用いた。まず，センサーとしての被覆線 は, $1 \mathrm{~mm} \varphi$ または $2 \mathrm{~mm} \varphi$ のポリウレタン被覆銅線を用 いて，現場で自由に交換できるようにし，また測定最大 波高は $4 \mathrm{~m}$ （若干短かったと思われる）と，増幅回路は 市販のものを前述した配虑のもとに若干改良して製作し た。

\section{（2）波高計の配置}

第 1 人工島棧橋は海面より約10～20m の高さにあるの で，容量型波高計を次の方法によって取付けた。棧橋の デッキに小型の手動ウィンチを取付け，これに約 $100 \mathrm{~kg}$ の鋼柱をおもりとして $4 \mathrm{~mm} \varphi$ のワイヤーロープで結び, これに $25 \mathrm{~mm} \varphi$ の鋼管をアース兼用の支持材として製作 した波高計せンサーを緊結し，同軸ケーブルによって増 幅器に連結した。このような波高計を図一1に示すよう に，合計 9 台を次の目的のために配置した。その $1 つ$ は，棧橋に沿う波浪の変形の観測のためであり，波高計 間の間隔は約 $36 \mathrm{~m}$ とした。これによって砕波後の波浪 の変形と各点での波向の観測も可能となり, 浅海におけ る波浪の屈折分散の特性も実測できるし，また長時間の 連続記録を解析すれば, サーフビートなどの諸現象の究 明にも役立てることができる。いま1つは，浅海におけ る波浪の方向スペクトルの究明のためであって, 棧橋先 端の事情により必ずしも適切な配置ではないが， 3 また

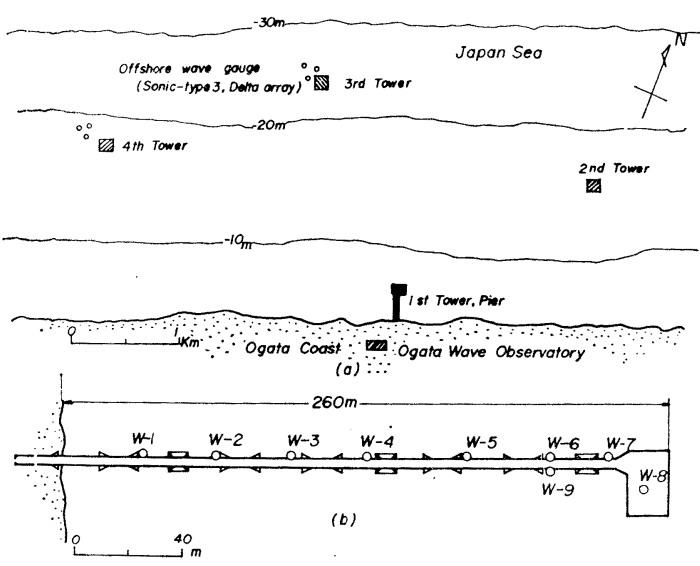

図一1 波高計の配置 
は 4 台の波高計群による同時観測結果から, 方向スペク トルが算出できるようにした。

\section{(3) 観測方法}

この観測は 1971 年 10 月より試みられ，1972 年 1 月 および1973年 1 月および 3 月とすでに 4 回実施されてき たが，そのうちの1月に行なわれた観測》は舞鶴海洋 気象台との協同観測の一部として実施されたものであ る。したがって，ほとんぞの場合，当波浪観測所の外洋 波浪観測装置（水深約 $20 \mathrm{~m}$, 階段抵抗式波高計 1 台, 超 音波型波高計 3 台によるデルタアレイを構成)を併用し， 漂砂・沿岸流・海浜変形などの観測も同時に行なわれ た。

波浪の観測はデーターレコーダーに 8 点同時記録し， また 9 点を同時にペンがきレコーダーに記録させること にして，原則として偶数時 $20 \mathrm{~min}$ 間の観測としたが， 波浪条件によっては適宣連続観測を行なった。它た, 来 襲波浪が碑波した場合には, その波浪記録にマークし， 扔抢よその砕波点を記入するととにし，さらに水深約 $7 \mathrm{~m}$ 付近の棧橋先端における波向をトランシットによっ てほぼ定時に観測した。

\section{3. 浅海における波浪特性に関する観測結果}

前述した方法によって観測された波浪記録它解析して 得られた二，三の興 味ある結果について 述べる。

（1）浅海におけ る波浪の变形

図-2 には波浪記 録をゼロアップクロ ス法によって読取 り, 有義波高の棧橋 に沿う変化の一例を 示す。図中には水深 変化も記入してある が, 離岸距離 $50 \mathrm{~m}$ 付 近では海底勾配が約 1/30，それより約 $250 \mathrm{~m}$ 付近までは約 1/130 ときわめて緩 やかである。この図 から明らかなよう に，波高が小さな場 合にはほぼ一様に減 衰しているが，波高 が大きくなると減少 してから増大したの ち再び減衰する傾向

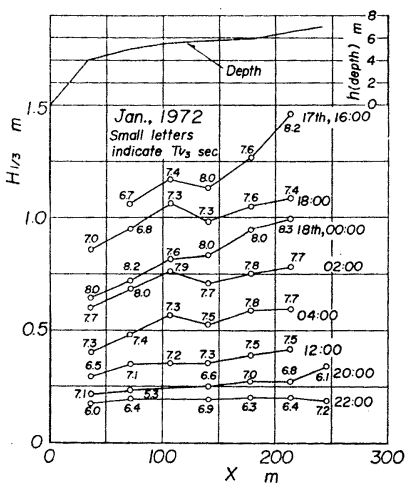

図一2 有義波高の変化

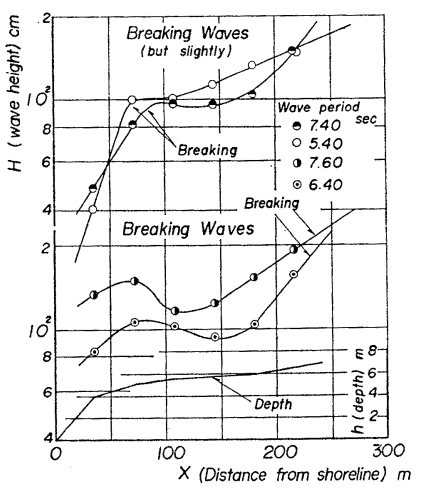

図一3 う衫りの砕波後の 波高変化
を示す。このととは図一3に示すように，うねりの各波 浪についての波高変化に扔いてさらに明確にされる。こ の図には，主として砕波後の波高変化が示されおり，砕 波してからの波高の減少はきわめて著しいが，離岸距離 約 $100 \mathrm{~m}$ 付近において波高はむしろ増大し, 再び砕波し て急速に減衰するととが見出される。この過程には浅海 における波の非線型性の卓越による波形変化が重要とな るようであり，いわゆるソリトンの発生を示唆する場合 もみられた。

波向によっては棧橋そのものの影響をうけるけれど も，棧橋方向よりわずか波向が片寄っている場合には， 図一2 に示した観測結果を用いて，波浪による海底摩擦 係数をかなりの精度で推定することができる。すなわ ち, 水深がほぼ一定な範囲觉対象とすることにすれば, 周知の Bretschneider および Reid の式を用いて海底摩 擦係数 $f$ を容易に推定することができる。たとえば，図 -2 に示した結果のうち波高がほぼ直線的に減少してい る波高芳小さい場合には， $f=0.02 \sim 0.03$ 程度となる が，図一3に示すような波高減衰を生ずる比較的波高の 大きな場合や砕波後の波高変化住しては， $f=0.1$ 程 度にも及ぶことが加かっている。したがって，このよう な波高減衰の観測結果から海底摩擦係数它推定する場合 には，少なくとも波形勾配などをパラメーターとして砕 波の影響置入することが必要であるうと思われる。

図一4 は波浪のエネルギースペクトルの棧橋に沿う変 化を示す一例である。これは資料数 1,000 個 $(\Delta t=0.625$ sec, $m=50, f=40)$ で Blackman-Tukey 法によって得ら れたものであるが，水深 $6.6 \mathrm{~m}$ より $4.0 \mathrm{~m}$ に至るに従っ て，非線型干渉によるエネルギ一の高周波側への移行と 海底摩擦や砕波による減少が確認される。をた, このよう な浅海における波浪においても，高周波側では $E_{f} \sim f^{-5}$

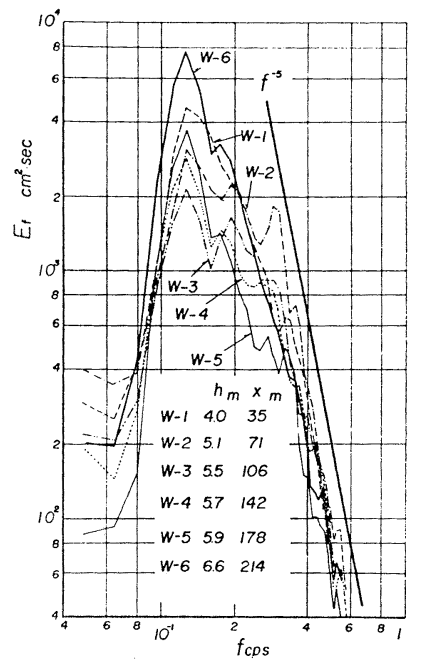

図-4 波浪のエネルギー スペクトルの変化 


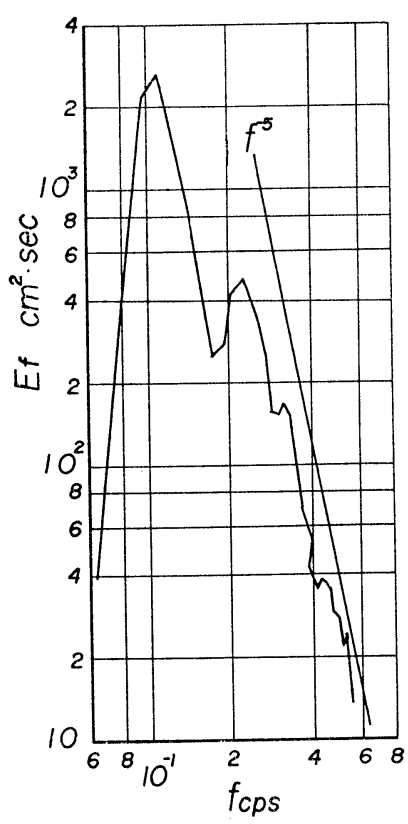

図一5方向スペクトルを算出した 波浪のエネルギースペクト ル $(h=6.6 \mathrm{~m}$ の場合 $)$

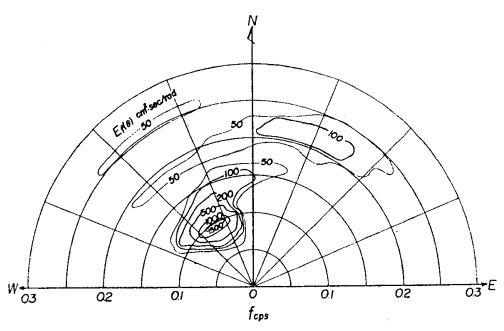

図一6 方向スペクトルの一例

則が成立しているようである。

\section{（2）波向および方向スペクトル}

図一5は波浪のエネルギースペクトルであり，ピーク 周波数の約 2 倍のところにも第 2 のピークをもつもので あるが，このときの方向スペクトルを図一6に示す。こ の方向スペクトルはいわゆる best fit の方法によって, 棧橋先端に持ける 4 台の波高計の同時記録から算出した

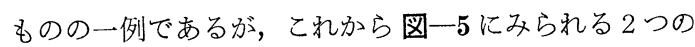
エネルギースペクトルのピークは，波浪の非線型性によ るものではなく，2方向からの波浪の重じゅうに起因し ていることがわかる。大潟海岸では，しばしばこのよう な場合が出現するので，波浪の非線型性を検討する場合 には，方向スペクトルの算出を行なって各成分波の合成 過程を明らかにしておくことが大切であらう。

一方，図一7 には波高計間の波浪記録の位相差から波 向を推定し，その波向の棧橋に沿う変化として示したも のの一例であって，ここでは比較のために図一6 の波浪 について図示してある。波向はN方向より左回りを正と
して示し，約 100 波のうち大きい波10波の波向の平均と して微小幅振波理論に基づいて推定してあるが，図一6 にみられる主方向と棧橋先端付近においてはほとえぞ一 致して扮り，また汀線に近づくにしたがって，次第に屈 折する傾向をある程度見出すととができる。したがっ て，各測点について各成分波の波向定算出するか，女る いは 3 台または 4 台の波高計群の同時記録から方向スペ クトルを推定すれば，屈折による波浪の分散特性とそれ に及ぼす非線型性や沿岸流などの影響を調べることもで きるであろう。

\section{（3）平均海面の変動}

前述したように，棧橋で数台の容量型波高計による長 時間の波浪観測を行なうと，ゼ口点の移動など電気的な 支障がほとんどないので，それらの記録定適切に解析す れば，平均海面の変動特性を見出すことができる。図一 8 は棧橋に沿う 6 台の波高計の長時間の同時記録を cut off frequency $0.051 \mathrm{cps}$ (波浪のエネルギースペクトル のピーク周波数の 2.5 倍）の low pass filterを使用し，資 料数 1000 個 ( $\Delta t=5 \mathrm{sec}, m=75, f=26)$ て BlackmanTukeyの方法によってスペクトル解析した結果の一例で ある。図中 $(6 \sim 8) 10^{-3} \mathrm{cps}$ 付近にみられるスペクトルの ピークは各測点においていずれも存在しており，これは surf beat と思われるが，(1.5 5) $10^{-2} \mathrm{cps}$ 付近に見ら れるピークは各測点によって周波数が相違し，汀線から 離れるにしたがって低周波側に移っている。

図一9 応したエネルギースペクトルの值の沖方向変化を示した ものである。この周波数の範囲についての積分值で図示 すべきであるが，便宜的にスペクトルの值とのもので表

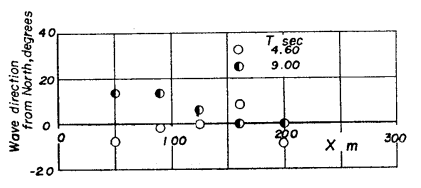

図一7 栈橋に沿う波向の変化の一例

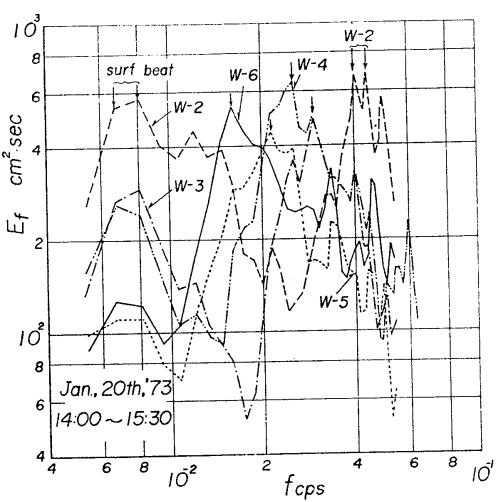

図一8 平均海面の変動のエネルギース ペクトルの変化の一例 




図一9 Surf beat の沖方向の変化



図-10 ピーク周波数の沖方向の変化

わしてあるにもかかわらず，沖方向へかなり著しく減少 していることが見出されるであろう。図一10にはさらに 高周波側に存在する各測点ごとのピーク周波数の沖方向 变化を示したものであって，乙れからその周波数が離岸 距離に密接に関係し，図中に示す長波の波速で反射した 場合の関係にきわめて近いことがわかる。すなわち，前 述したように, この海岸は汀線付近では約 $1 / 30$ 程度の勾 配をむつので，波浪の周期によっては反射安無視するこ とができず, 特に, $10^{-2} \mathrm{cps}$ 程度の長波性の海面変動に対 しては当然のことといわねばならない。言い換えれば， 波浪を含む海面变動にはかなり広周波数の水位変動が重 じゅうされているが，そのなかで波高計の位置で定めら れる離岸距離を往復する水位変動の周期に対応した波が 测定上卓越することになるのである。したがって，一般に 海岸の 1 点における水位变動の観測結果から, surf beat などの比較的長周期の波動現象の特性を究明する場合に は, 以上のような測定上現われる卓越した水位変動を包 含する可能性があるので注意すべきであろう。

\section{4. 結語}

以上，長大棧橋に容量型波高計群を設置して波浪の同 時観測を実施した結果の概要について述べた。観測結果 を解析して得られた成果のうち，乙れまであまり報告さ れていなかった興味ある若干の結果を示すことができ た。特に, 浅海における波浪の変形に関しては, 砕波後 の波高変化や海底摩擦係数の推定などの再検討ができる に值する多くの観測記録它得ている。また，これらの波 浪観測の経験から, 容量型波高計群を用いた長大棧橋の 利用は，この種の観測法としてきわめて有効であると考 えられるので, 今後さらに改良を加えて, 波浪観測の推 進に努めたいと考えている。

この観測方法の計画および実施には，主として著者ら があたったが，海洋気象台との協同観測をはじめとして 大潟波浪観測所での集中観測に多大の協力をされた波浪 観測グループの諸见, 特に白井亨助手, 中村重久助手, 芝野照夫助手をはじめ海岸災害部門関係の諸君に厚く謝 意を表明する次第である。また，観測結果の考察におい て適切なご教示をいただいた工学部岩垣雄一教授に深謝 するとともに，この研究が文部省科学研究費による研究 成果の一部であることを付記する。

\section{参考 文 献}

1) 岩垣雄一：長大棧橋による沿岸海況の観測, 沿岸海 洋研究ノ一ト, 第 5 巻, 第 1 号, 1966, pp. 41 45.

2）川上善久. 広本文泰・阿部淑輝 - 須藤茂 : 名古 屋港における波浪観測一容量型波高計の現地一の 適用一，港湾技研資料，No. 32,1967 , pp. 57 80.

3）土屋義人（波浪観測グループ代表）：日本海沿岸 に尔ける冬期波浪の協同観測，京大防災研年報， 第 15 号, 1973, pp. 29 39.

訂正：図一7 に間違いがあり， $T=9 \mathrm{sec}$ で $x=160 \mathrm{~m}$ および $200 \mathrm{~m}$ のものの波向は約 $33^{\circ}$ である。 